\title{
KERNVILLE
}

\section{Containment Data Report}

\author{
Billy Hudson \\ Ted Stubbs \\ Ray Heinle
}

\section{December 1994}

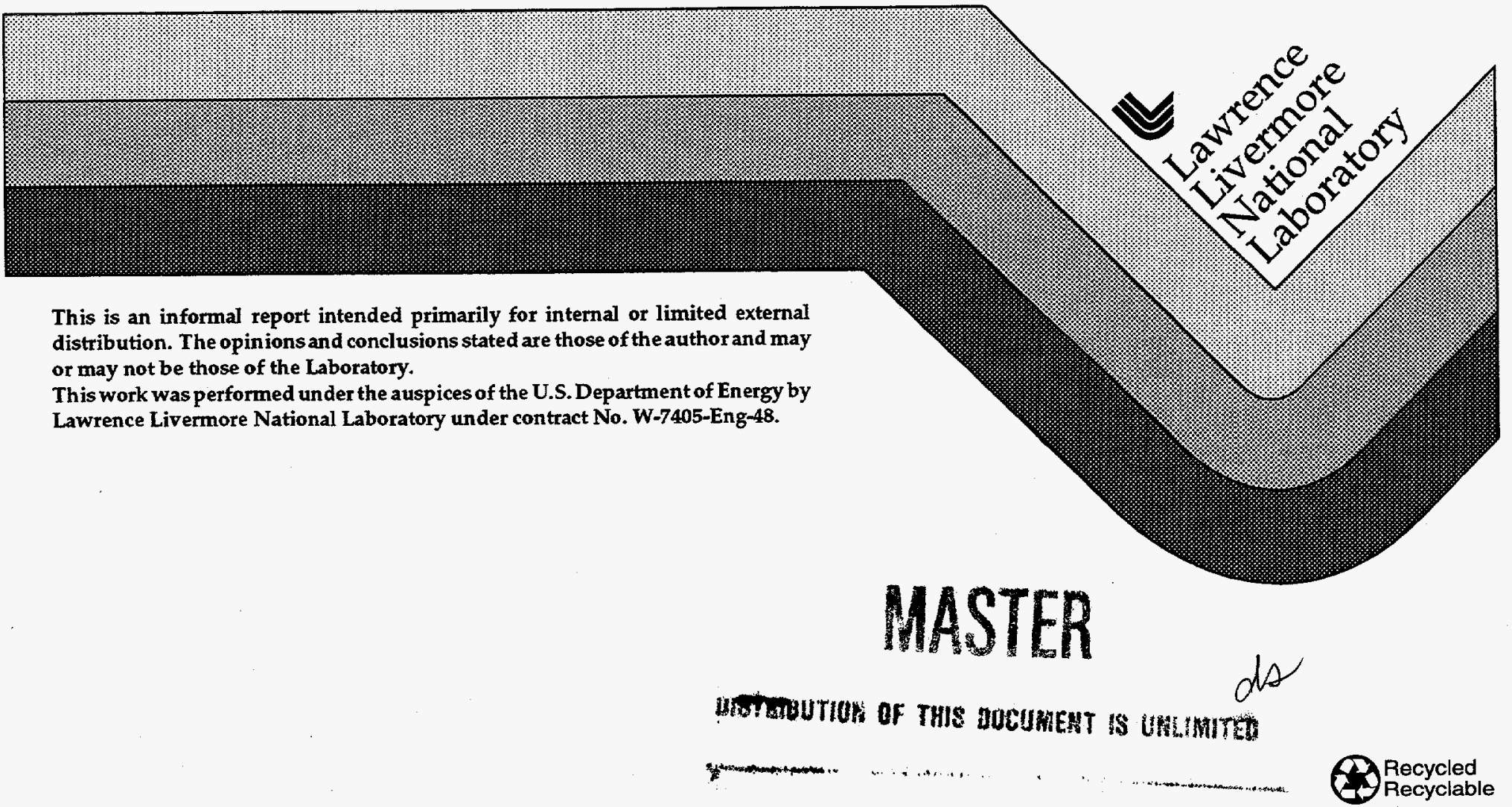




\section{DISCLAMMER}

This document was prepared as an account of work sponsored by an agency of the United States Government. Neither the United States Government nor the University of California nor any of their employees, makes any warranty, express or implied, or assumes any legal liability or responsibility for the accuracy, completeness, or usefulness of any information, apparatus, product, or process disclosed, or represents that its use would not infringe privately owned rights. Reference herein to any specific commercial product, process, or service by trade name, trademark, manufacturer, or otherwise, does not necessarily constitute or imply its endorsement, recommendation, or favoring by the United States Government or the University of California. The views and opinions of authors expressed herein do not necessarily state or reflect those of the United States Government or the University of California, and shall not be used for advertising or product endorsement purposes.

This report has been reproduced directly from the best available copy.

Available to DOE and DOE contractors from the

Office of Scientific and Technical Information

P.O. Box 62, Oak Ridge, TN 37831

Prices available from (615) 576-8401, FTS 626-8401

Available to the public from the

National Technical Information Service

U.S. Department of Commerce

5285 Port Royal Rd.

Springfield, VA 22161 


\section{DISCLAIMER}

This report was prepared as an account of work sponsored by an agency of the United States Government. Neither the United States Government nor any agency thereof, nor any of their employees, make any warranty, express or implied, or assumes any legal liability or responsibility for the accuracy, completeness, or usefulness of any information, apparatus, product, or process disclosed, or represents that its use would not infringe privately owned rights. Reference herein to any specific commercial product, process, or service by trade name, trademark, manufacturer, or otherwise does not necessarily constitute or imply its endorsement, recommendation, or favoring by the United States Government or any agency thereof. The views and opinions of authors expressed herein do not necessarily state or reflect those of the United States Government or any agency thereof. 


\section{DISCLAIMER}

Portions of this document may be illegible in electronic image products. Images are produced from the best available original document. 


\begin{tabular}{|c|c|c|}
\hline Classification Guide & Topic Number & Subject \\
\hline COK-88-024 & 1.5 .6 & Event announcement \\
\hline NV-89-18 & & Event announcement \\
\hline TCG-WT-1 & 1113 & Contractor identification \\
\hline TCG-WT-1 & 1121 & Personnel identification \\
\hline TCG-WT-1 & 1210 & Geology \\
\hline TVG-WT-1 & 1260 & Crater (map) \\
\hline TCG-WT-1 & 1413 & Statement concerning venting \\
\hline TCG-WT-1 & 1452 & Event announcement \\
\hline TCG-WT-1 & 1831 & Depth of burial \\
\hline TCG-WT-1 & 1843 & Stemming material, amount,etc \\
\hline TCG-WT-1 & 1925 & Diagnostic canister dimensions \\
\hline TCG-WT-1 & 3542.3 & Ground motion \\
\hline TCG-WT-1 & 4810 & Radiation measurement \\
\hline TCG-WT-1 & 4820 & $\begin{array}{l}\text { Acceleration, pressure, } \\
\text { temperature measurement }\end{array}$ \\
\hline
\end{tabular}


KERNVILLE Instrumentration Summary

\begin{tabular}{|l|l|l|l|}
\hline Instrumentation & $\begin{array}{l}\text { Fielded on } \\
\text { this Event }\end{array}$ & $\begin{array}{l}\text { Data } \\
\text { Return }\end{array}$ & $\begin{array}{l}\text { Present in } \\
\text { this Report }\end{array}$ \\
\hline Plua Emplacement & yes & yes & yes \\
\hline Radiation & no & - & - \\
\hline Pressure & no & - & - \\
\hline Motion & & & \\
Free Field & no & - & - \\
Surface & yes & yes & yes \\
Phug & no & - & - \\
Stemming & no & - & - \\
Surface Casing & no & - & - \\
Emplacement Pipe & no & - & - \\
\hline Hydrovield (a) & yes & yes & no \\
\hline Collapse (b) & yes & no & - \\
\hline Stress & no & - & - \\
\hline Strain (c) & yes & yes & yes \\
\hline Other Measurements & no & - & - \\
\hline
\end{tabular}

(a) CORRTEX and SLIFER in emplacement and satellite holes.

(b) EXCOR in emplacement and satellite holes.

(c) Strain gages on emplacement pipe.

Event Personnel

\section{Containment Physics}

B. Hudson

E. Woodward

V. Wheeler

J. Kalinowski

T. Stubbs
LLNL

LLNL

LLNL

EG\&G/AVO

$E G \& G / A V O$
Instrumentation

T. Valk.

C. Cordill

LLNL

R. Salizar

LLNL

EG\&G/AVO

B. Bellow

EG\&G/NVO

W. Webb

$E G \& G / N V O$ 


\section{Contents}

1. Event Description

1.1 Containment summary . $\quad . \quad$. $\quad . \quad$.

1.1 Site

1.2 Instrumentation.

2. Emplacement

2.1 Pipe strain

2.2 Plug levels and temperature.

3. Stemming Performance

4. Motion

16

References 


\section{Event Description}

\subsection{Containment summary}

The KERNVILLE experiment was executed in Hole U20ar of the Nevada Test Site at 10:10 PST on February 15, 1988. on the Pahute Mesa of the Nevada Test Site as indicated in figure 1.1. All early phenomena observed appeared normal, however, cavity collapse reached the ground surface producing a crater having a mean radius of about $61 \mathrm{~m}$ and a maximum depth of about $12 \mathrm{~m}$.

No radiation arrivals were detected; the KERNVILLE event containment was considered satsfactory.

\subsection{Site}

The working point of $540 \mathrm{~m}$ was in layered tuffs about $30 \mathrm{~m}$ above the static water level (SWL), as seen in figure $1.2^{(1)}$. Figure 1.2 also contains a geologic map of the region near hole U20ar.

Stemming of the $3.05 \mathrm{~m}$ diameter emplacement hole followed the plan shown in Fig. 1.3. The $31 \mathrm{~cm}$ diameter satellite hole was stemmed to within a few feet of the top with grout. A log of the stemming operations was maintained by Holmes \& Narver(2).

\subsection{Instrumentation}

The instrumentation fielded by the containment group for the KERNVILLE event was confined to emplacement diagnostics, stemming quality assurance, treaty verification measurements, and standard motion stations. Figure 1.4 is a schematic layout of the instrumentation designed to monitor the emplacement and stemming procedures of the KERNVILLE event. Further details of the instrumentation are given in Reference 3 . There was no final engineering report issued for this event.

Two EXCOR stations were fielded in the satellite hole to observe the progression of postshot collapse. 
Yield verification measurements in the emplacement hole consisted of two CORRTEX stations (figure 1.4) and in the satellite hole two CORRTEX stations, two SLIFER stations and two pin-switch arrays (figure 1.5). Results of these experiments are reported elsewhere(4).

Surface motion measurements consisted of a vertically oriented station placed $15.24 \mathrm{~m}$ horizontally from Surface-Ground-Zero (SGZ) and $0.6 \mathrm{~m}$ below the ground surface and a triaxial station mounted in the recording trailer about $270 \mathrm{~m}$ from SGZ. Additionally, a geophone station was fielded in the ground surface near the recording trailer. Both of the motion transducers in this station were ranged for motion of very low amplitude and were greatly over-driven by the explosion signals.

Atmospheric pressure was monitored by a transducer mounted inside the recording trailer and ported through the wall to the outside. The recording time period (about 3 hours) was too short to sample the long-term changes in the atmosphere, the porting precluded an accurate representation of the airblast waveform, and the signal included many noise spikes. For these reasons the signal is not shown in this report.

The emplacement pipe strain data collected during emplacement and stemming were taken from the stemming log maintained by Holmes \& Narver ${ }^{(2)}$. The curing temperature data of the SGC plugs are not available. 


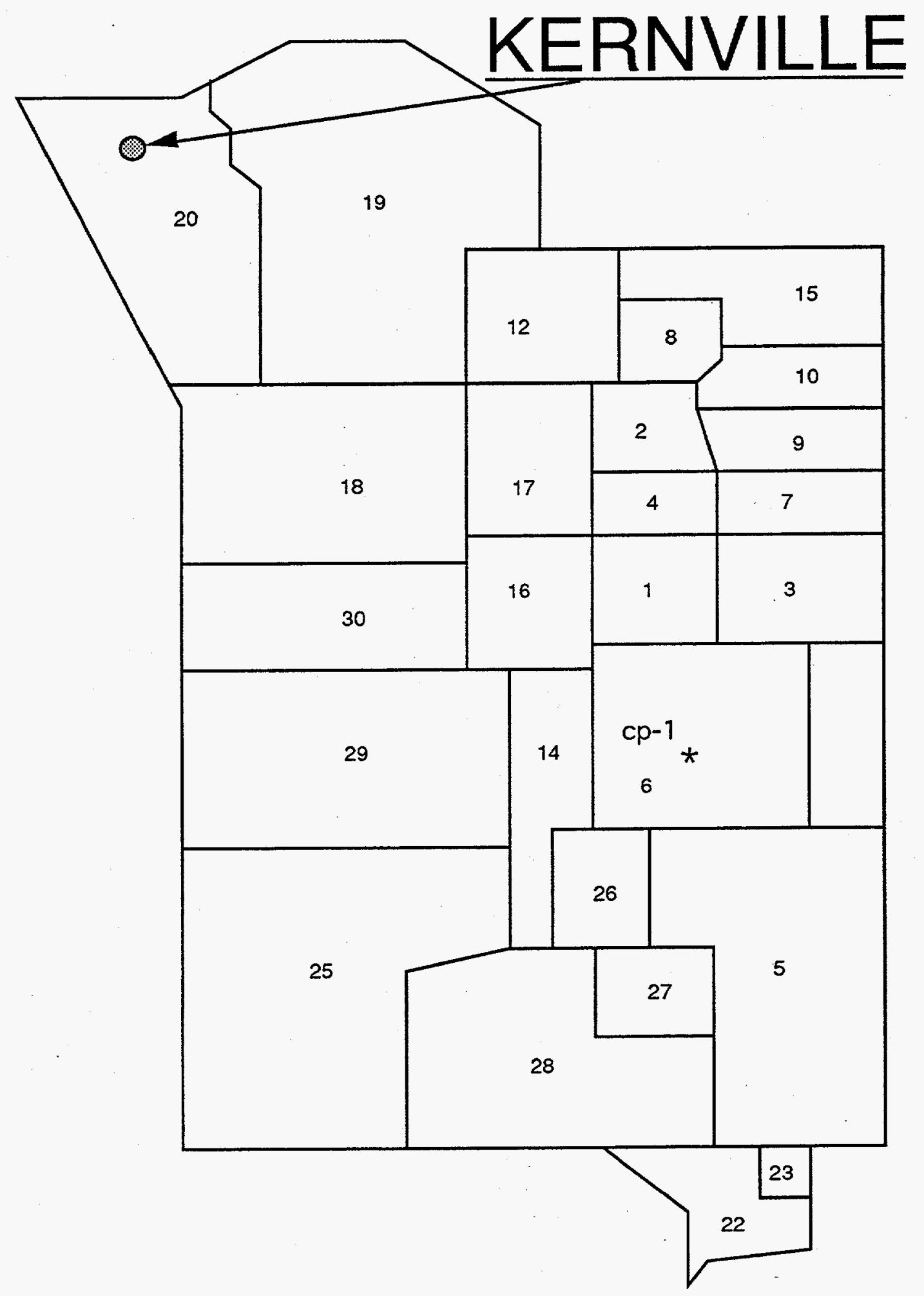

Figure 1.1 Map of the Nevada Test Site indicating the location of hole U20ar. 

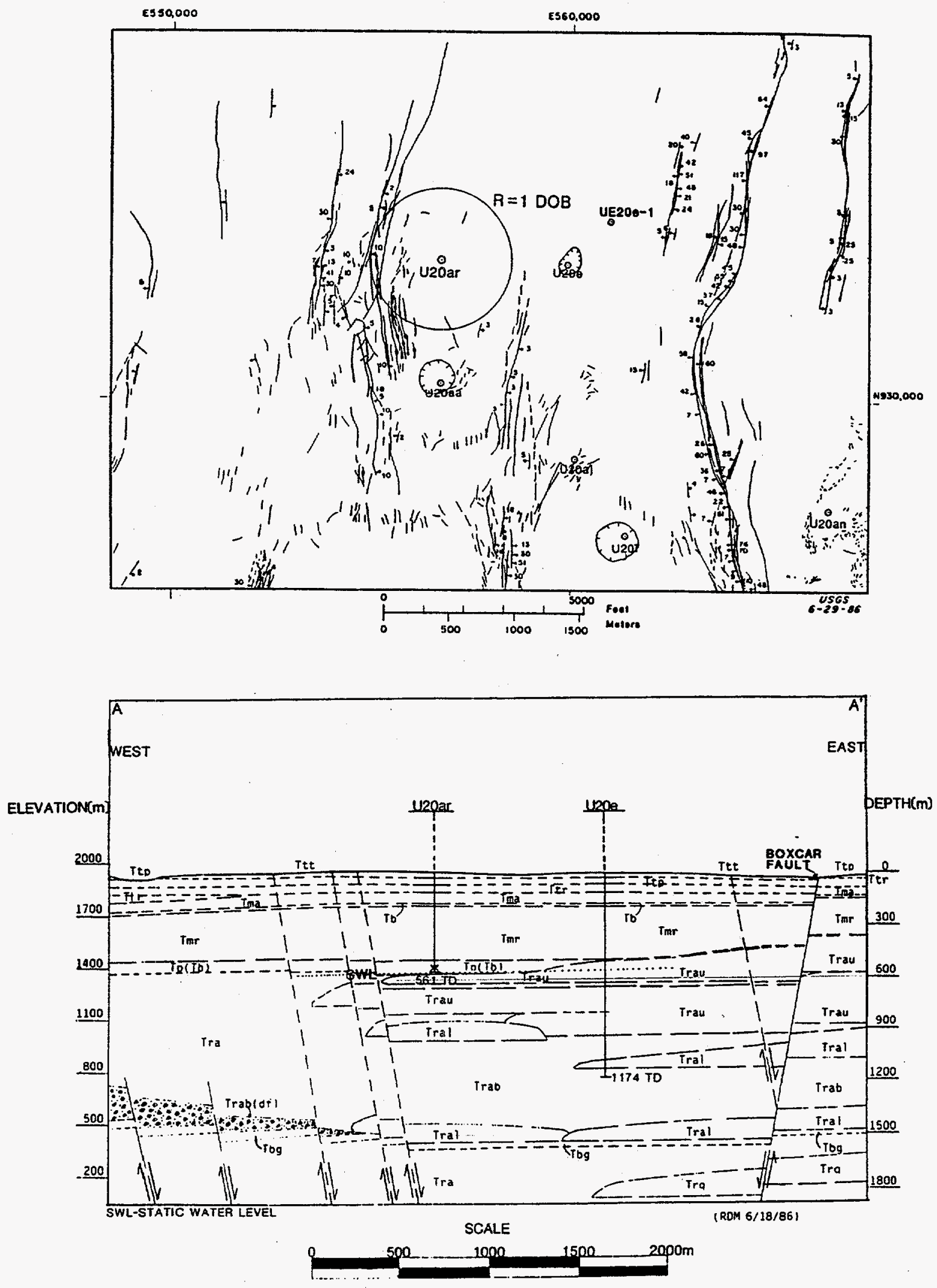

A-A' GEOLOGIC CROSS SECTION THROUGH U2Oar

Figure 1.2 Geologic cross section through hole U20ar. 


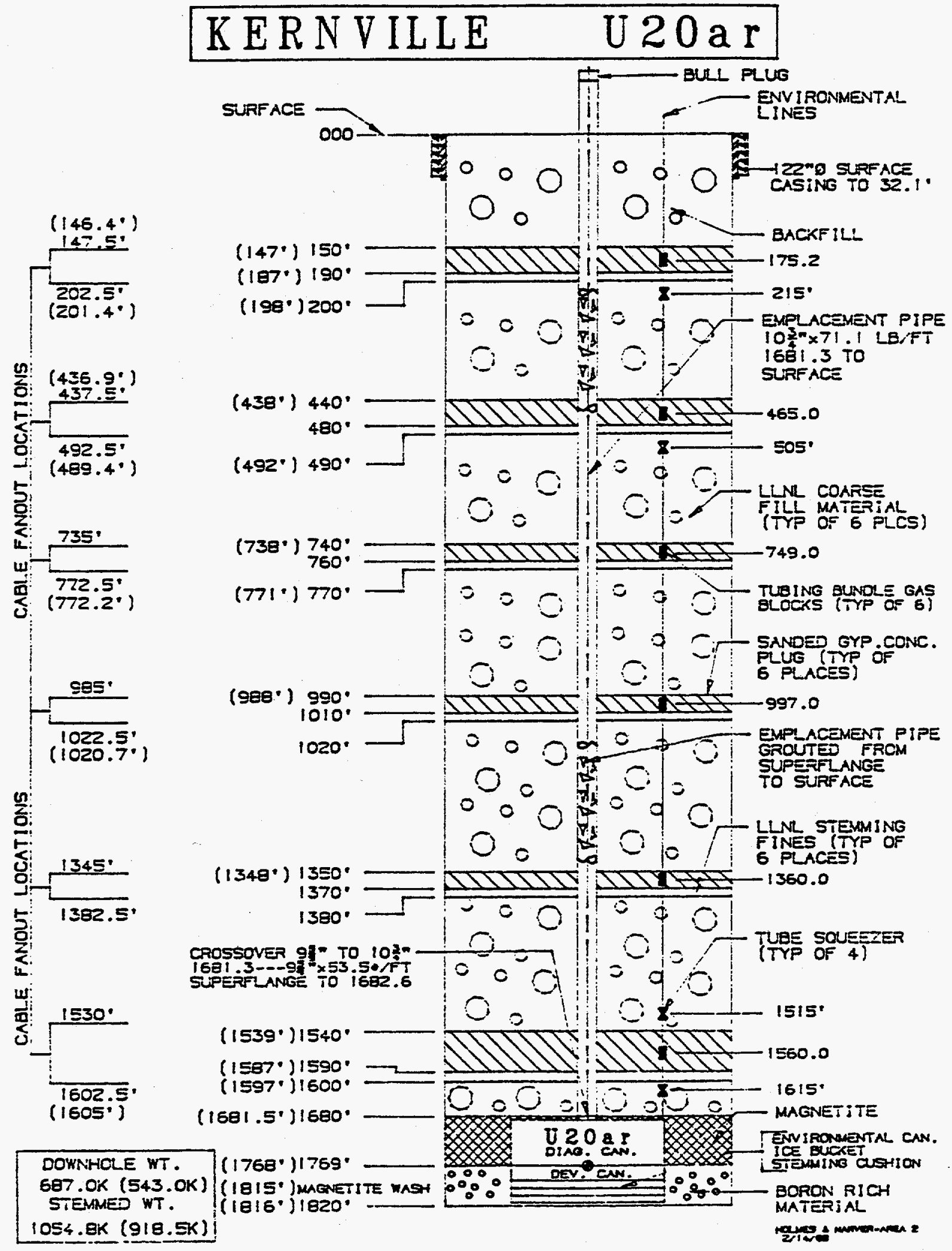

Figure 1.3 As-built stemming plan for the event KERNVILLE, in Hole U20ar. 


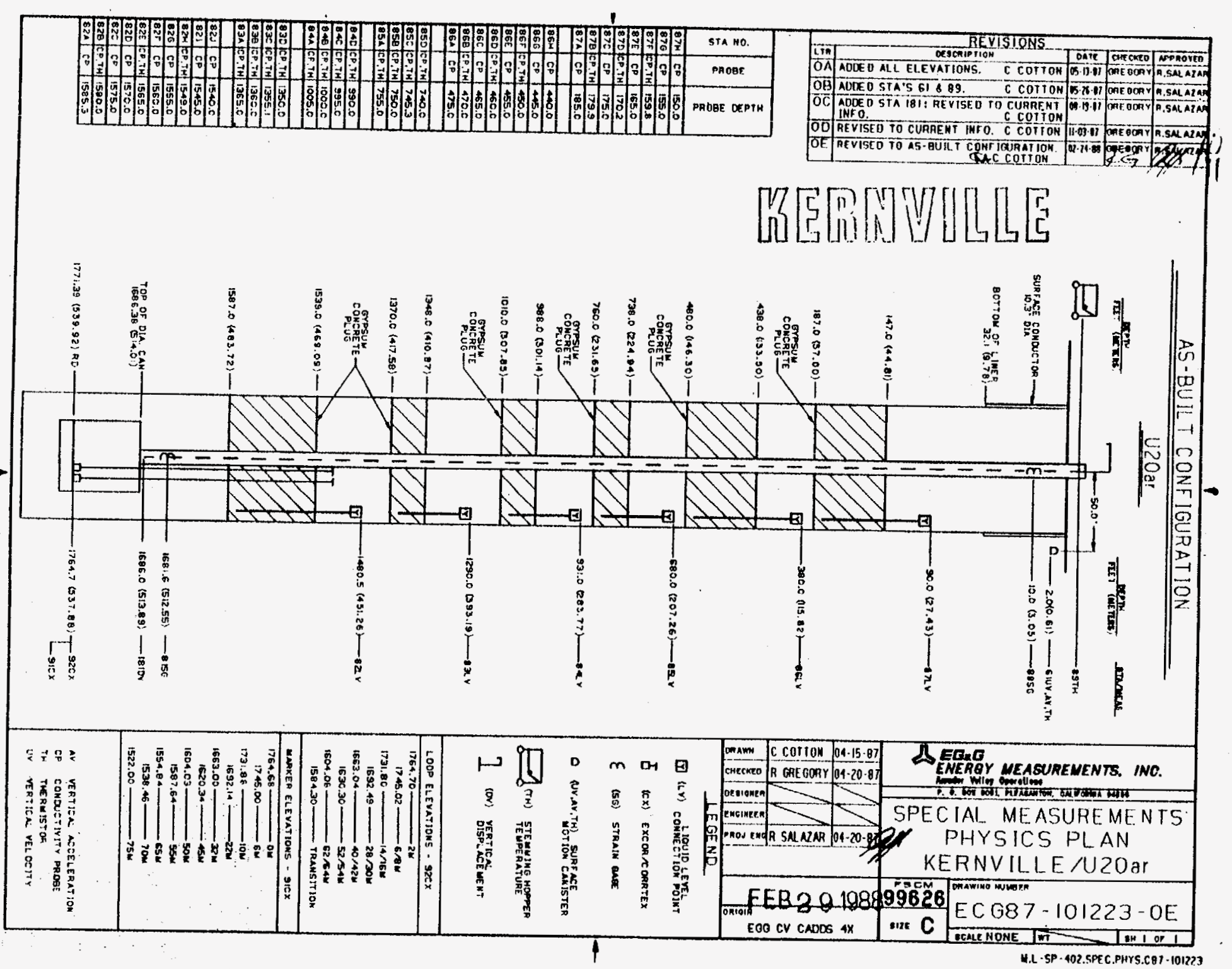




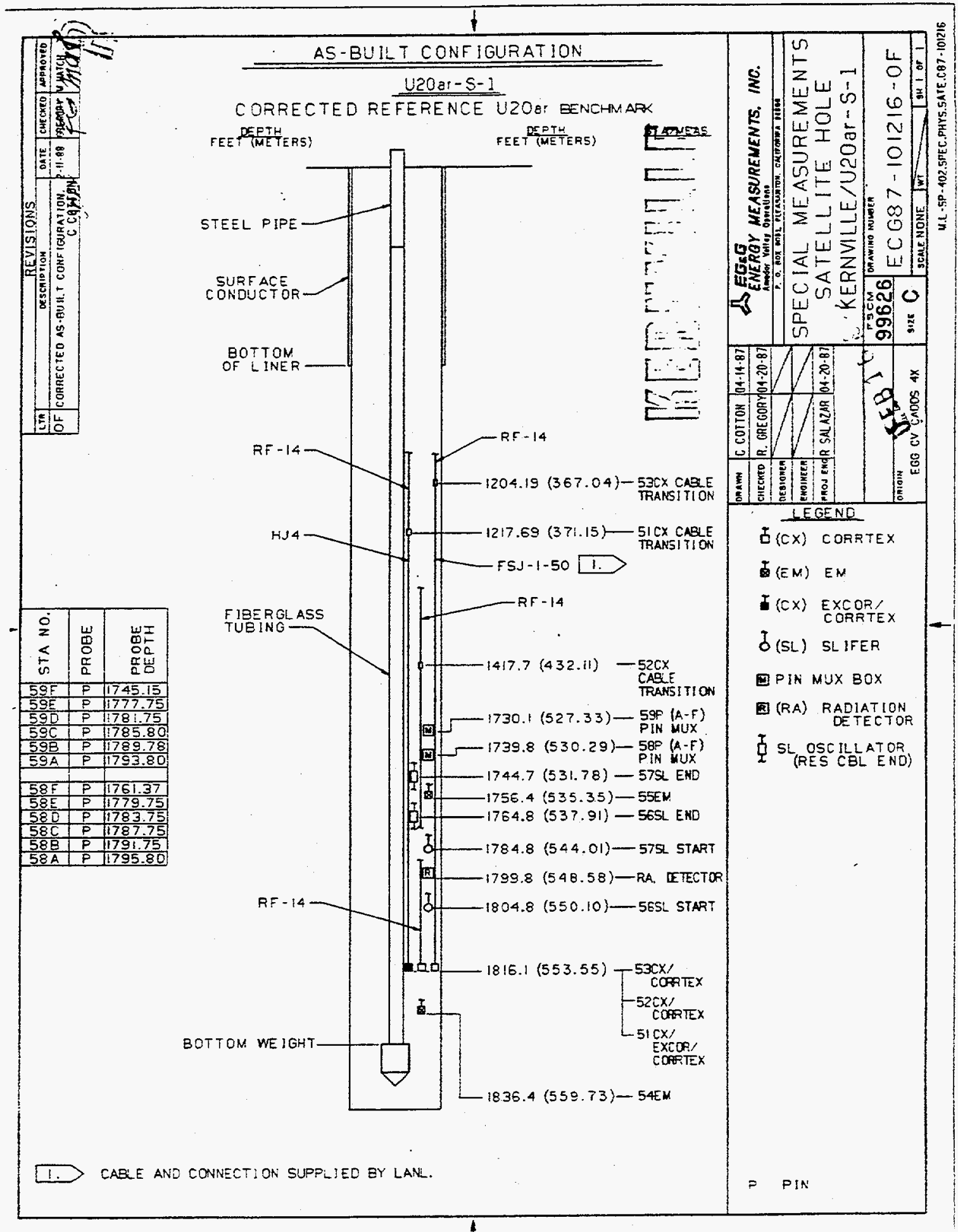

Figure 1.5 As-built instrumentation plan for satellite hole U20ar-S1 on the KERNVILLE event. 


\section{Emplacement}

2.1 Pipe strain

Figure 2.1 is the strain history measured on the emplacement pipe and read from the stemming $\log (2)$ during stemming of the KERNVILLE experiment. The emplacement pipe was instrumented with a strain gage station on the final pipe section just below the load collar, (Station 88), and another station just above the diagnostics canister (Station 81).

\subsection{Plug levels and temperature}

The emplacement of each of the six SGC plugs was monitored with an array of conductivity probes and thermistors. The locations of each of the components (probes) of these arrays are shown in Figure 1.4. The upper and lower boundary positions of the plugs were determined by tag lines. Figures 2.2 through 2.7 contain plots of the arrival times of the SGC slurry as a function of depth (as determined from the conductivity probes and tag lines) and SGC temperature histories. These data indicate that all plugs were emplaced as planned.

The satellite hole was grouted from depth to within a few feet of the ground surface. 


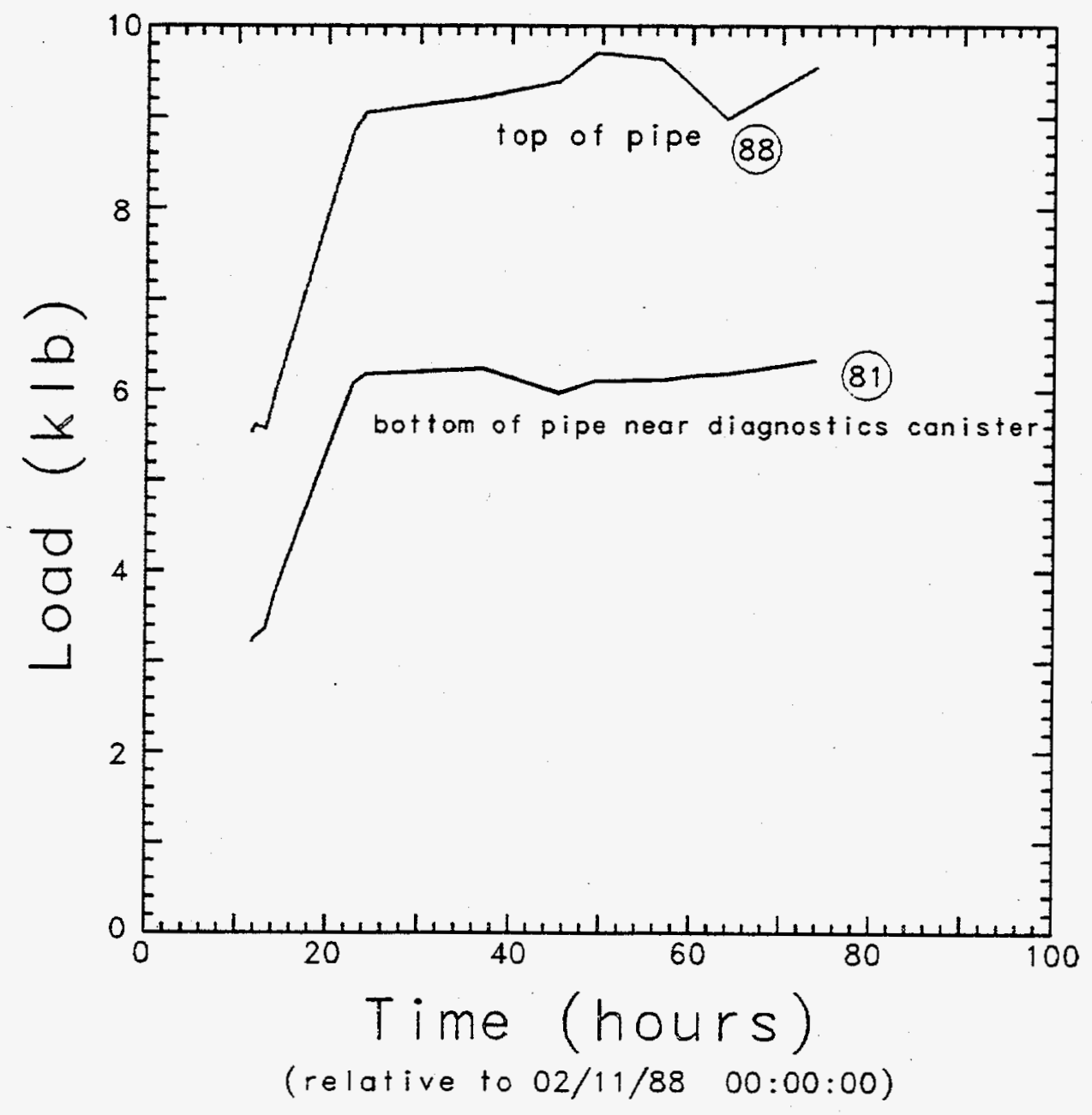

Figure 2.1 Strain measurements during the stemming at stations 88 (near the top of the emplacement pipe), and 81, (on the emplacement pipe just above the diagnostics canister). 


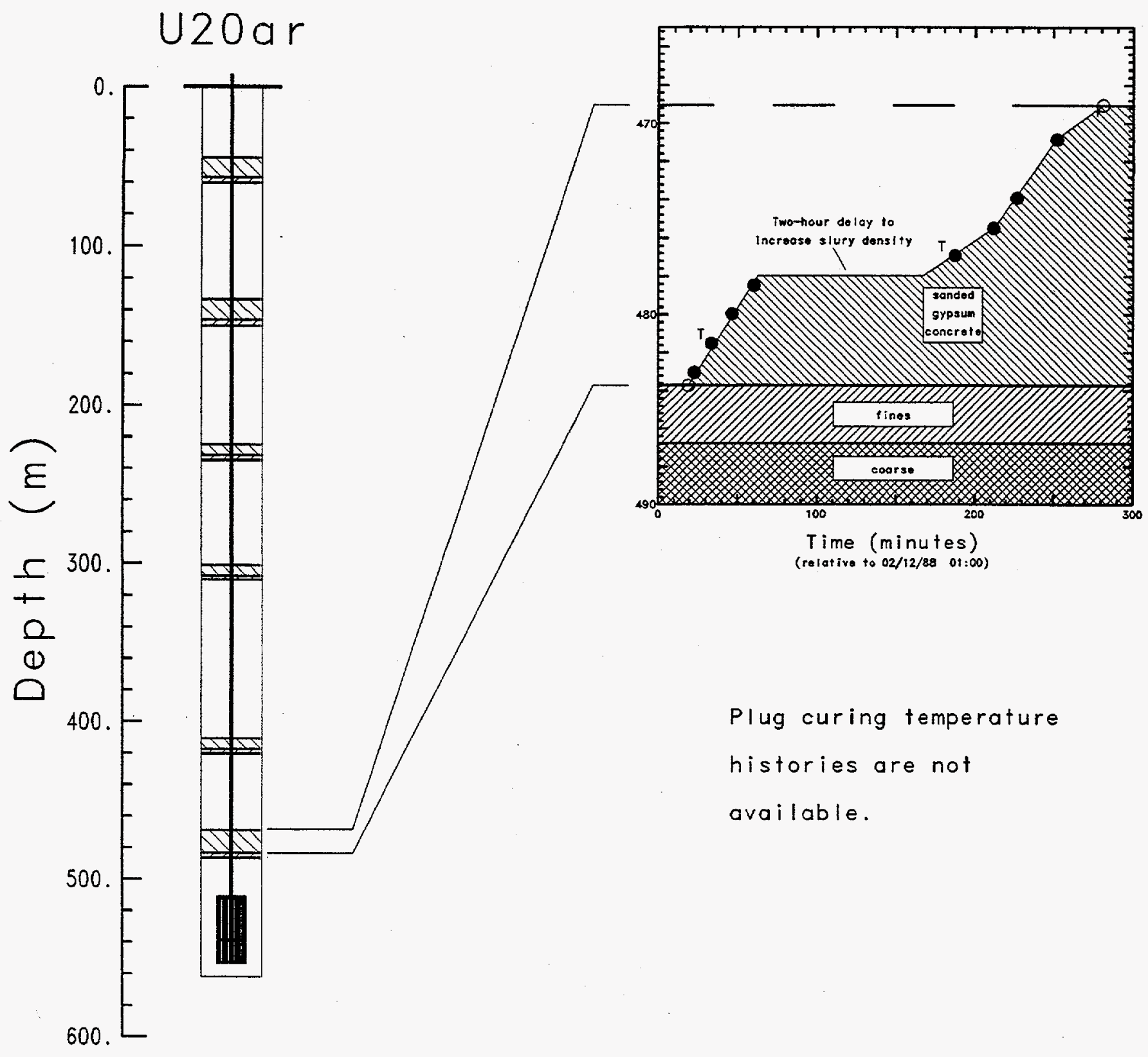

Figure 2.2 Emplacement diagnostics data at SGC plug \#1. The upper and lower boundaries of the plug were determined with a tag line. Solid symbols indicate the elevation of the probes; open symbols are at the tag depths. Probes annotated with ' $T$ ' included temperature sensors. 


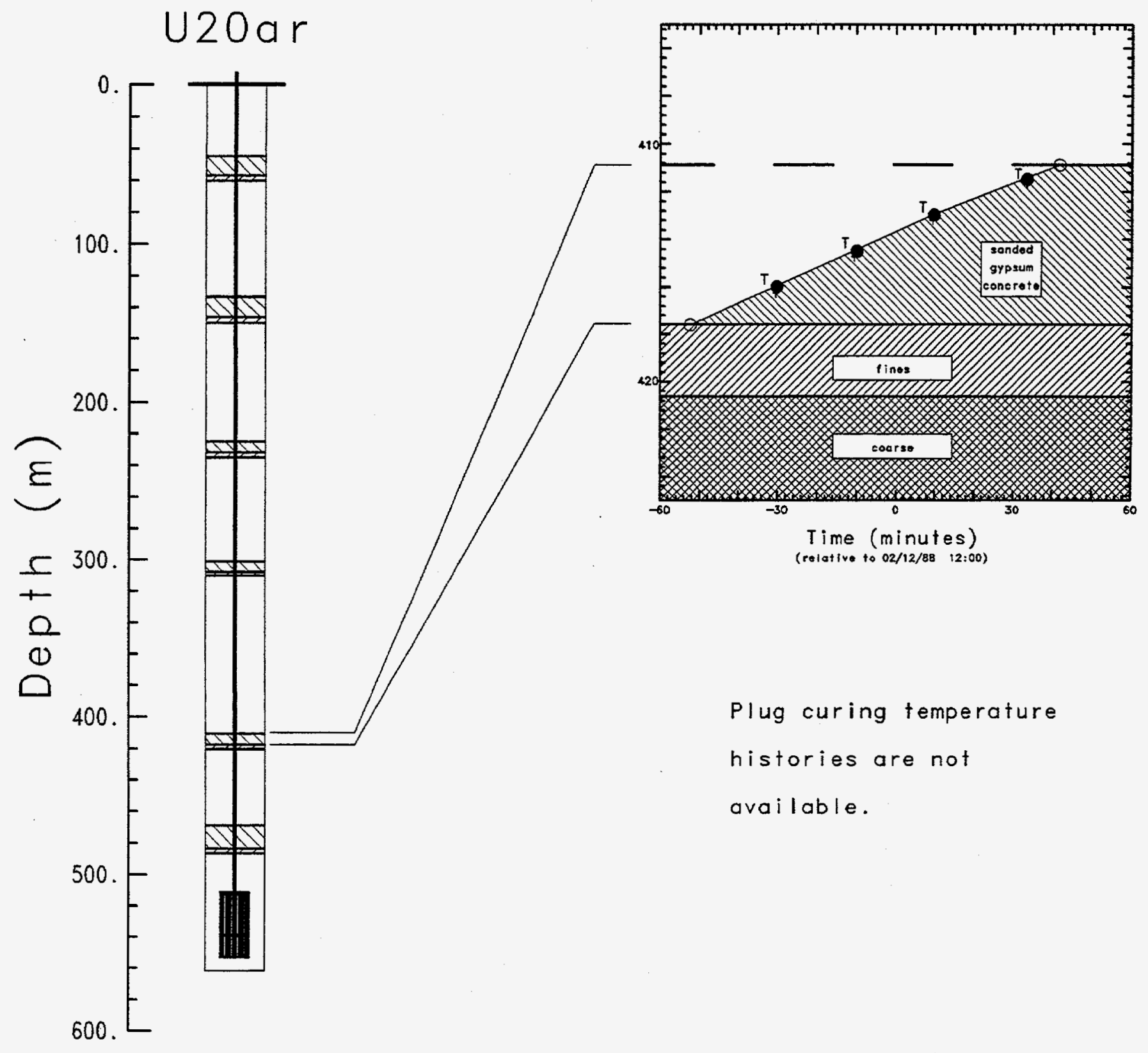

Figure 2.3 Emplacement diagnostics data at SGC plug \#2. The upper and lower boundaries of the plug were determined with a tag line. Solid symbols indicate the elevation of the probes; open symbols are at the tag depths. Probes annotated with ' $T$ ' included temperature sensors. 


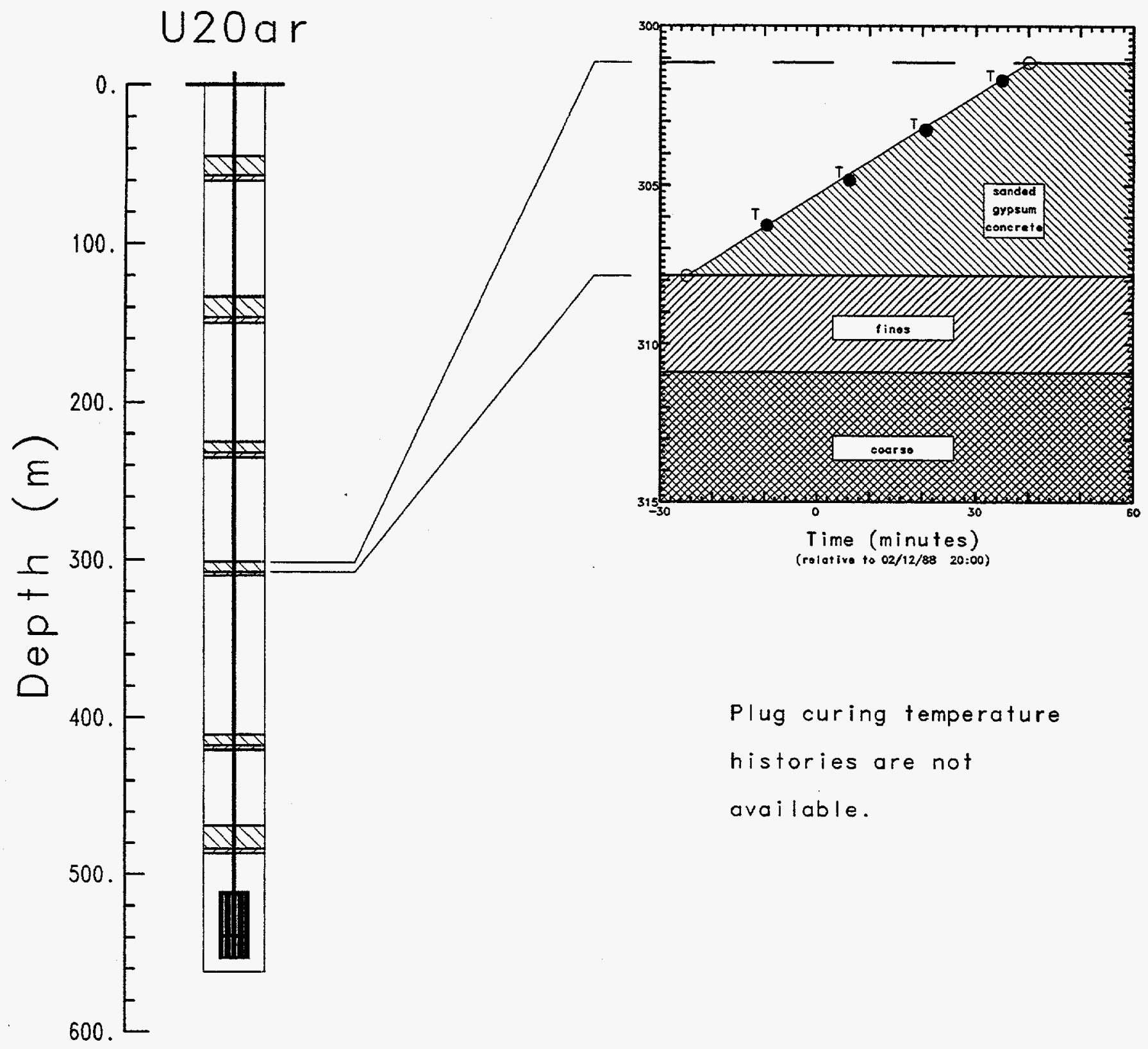

Figure 2.4 Emplacement diagnostics data at SGC plug \#3. The upper and lower boundaries of the plug were determined with a tag line. Solid symbols indicate the elevation of the probes; open symbols are at the tag depths. Probes annotated with ' $\mathrm{T}$ ' included temperature sensors. 


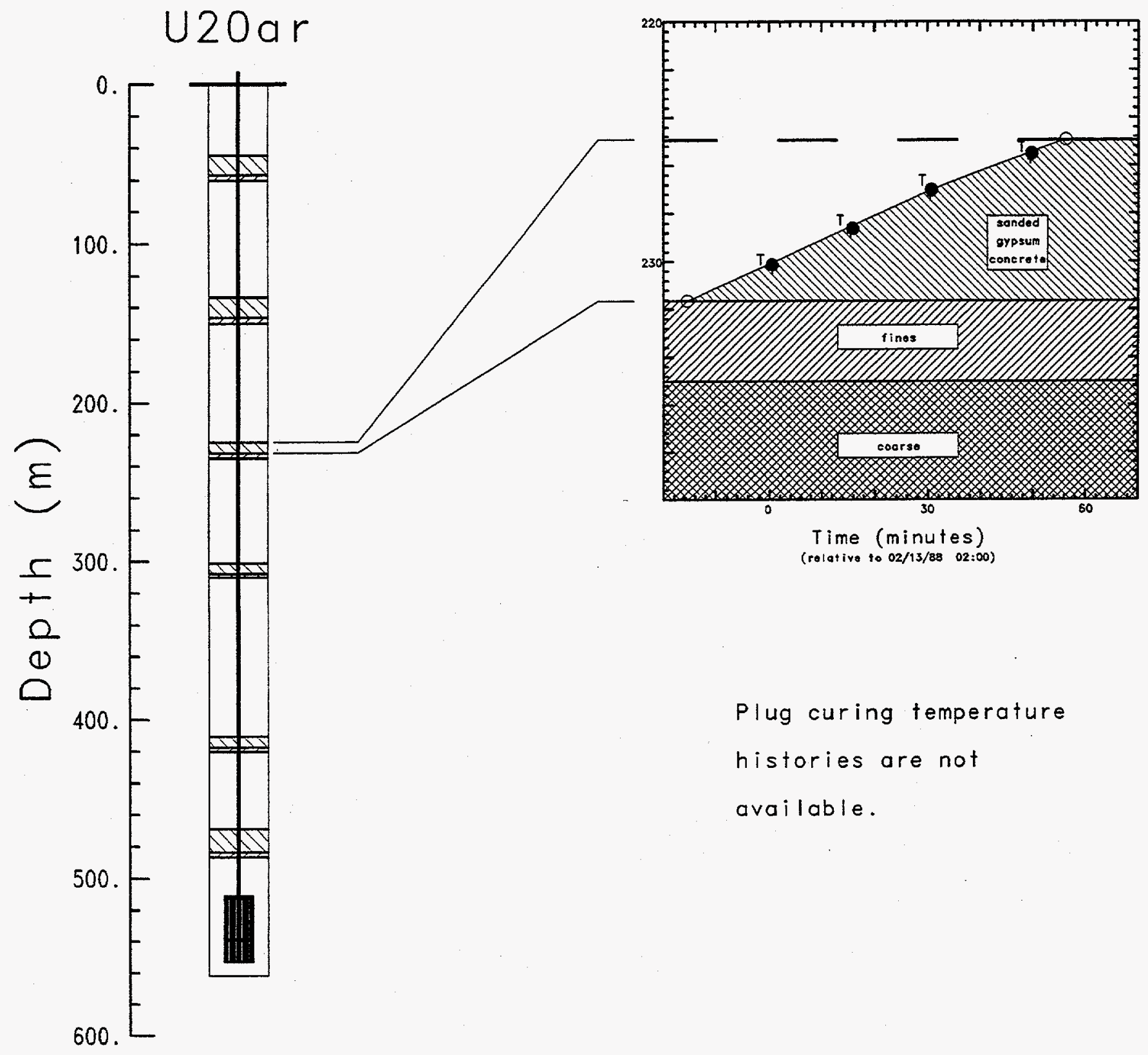

Figure 2.5 Emplacement diagnostics data at SGC plug \#4. The upper and lower boundaries of the plug were determined with a tag line. Solid symbols indicate the elevation of the probes; open symbols are at the tag depths. Probes annotated with ' $T$ ' included temperature sensors. 


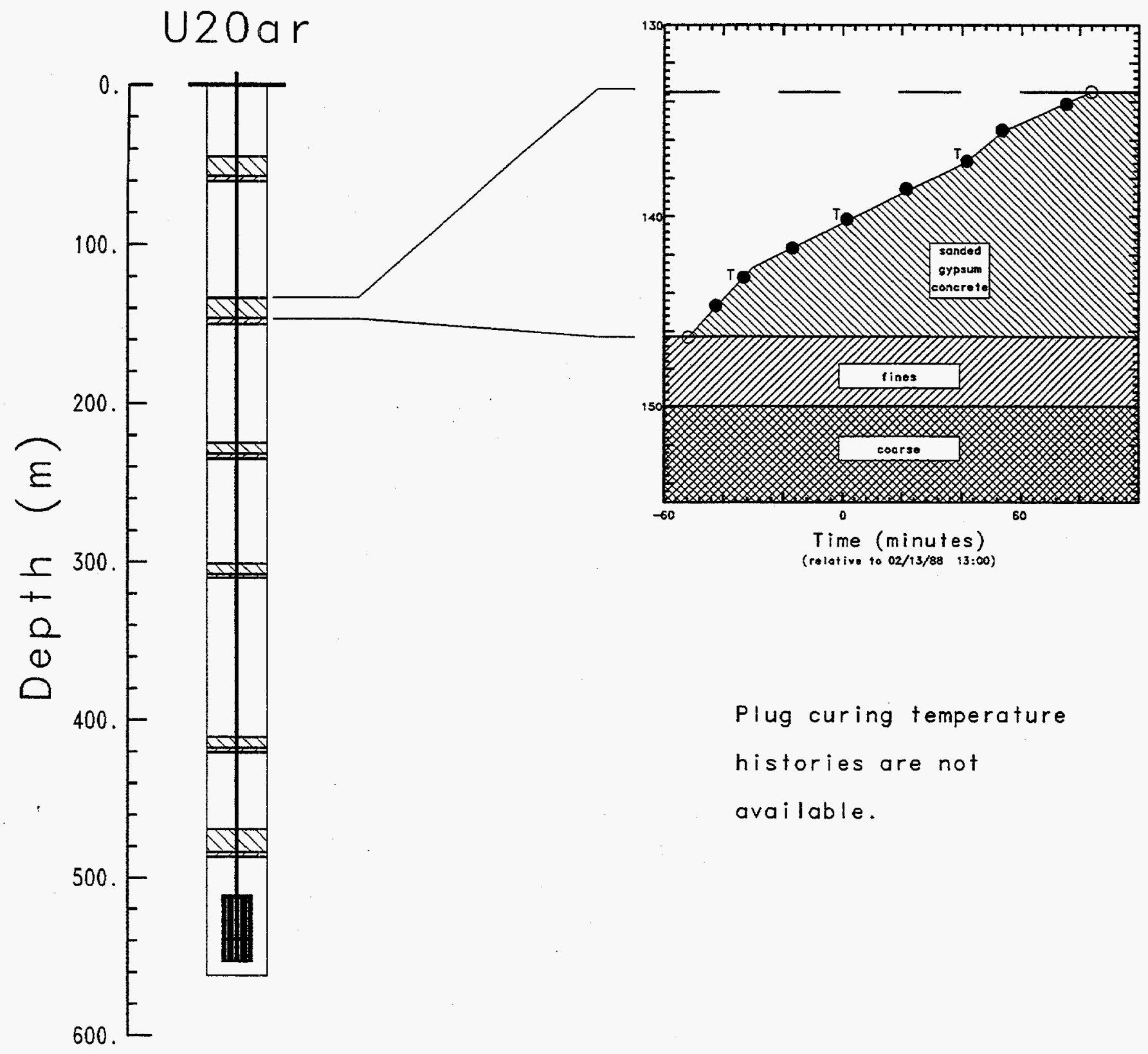

Figure 2.6 Emplacement diagnostics data at SGC plug \#5. The upper and lower boundaries of the plug were determined with a tag line. Solid symbols indicate the elevation of the probes; open symbols are at the tag depths. Probes annotated with ' $T$ ' included temperature sensors. 


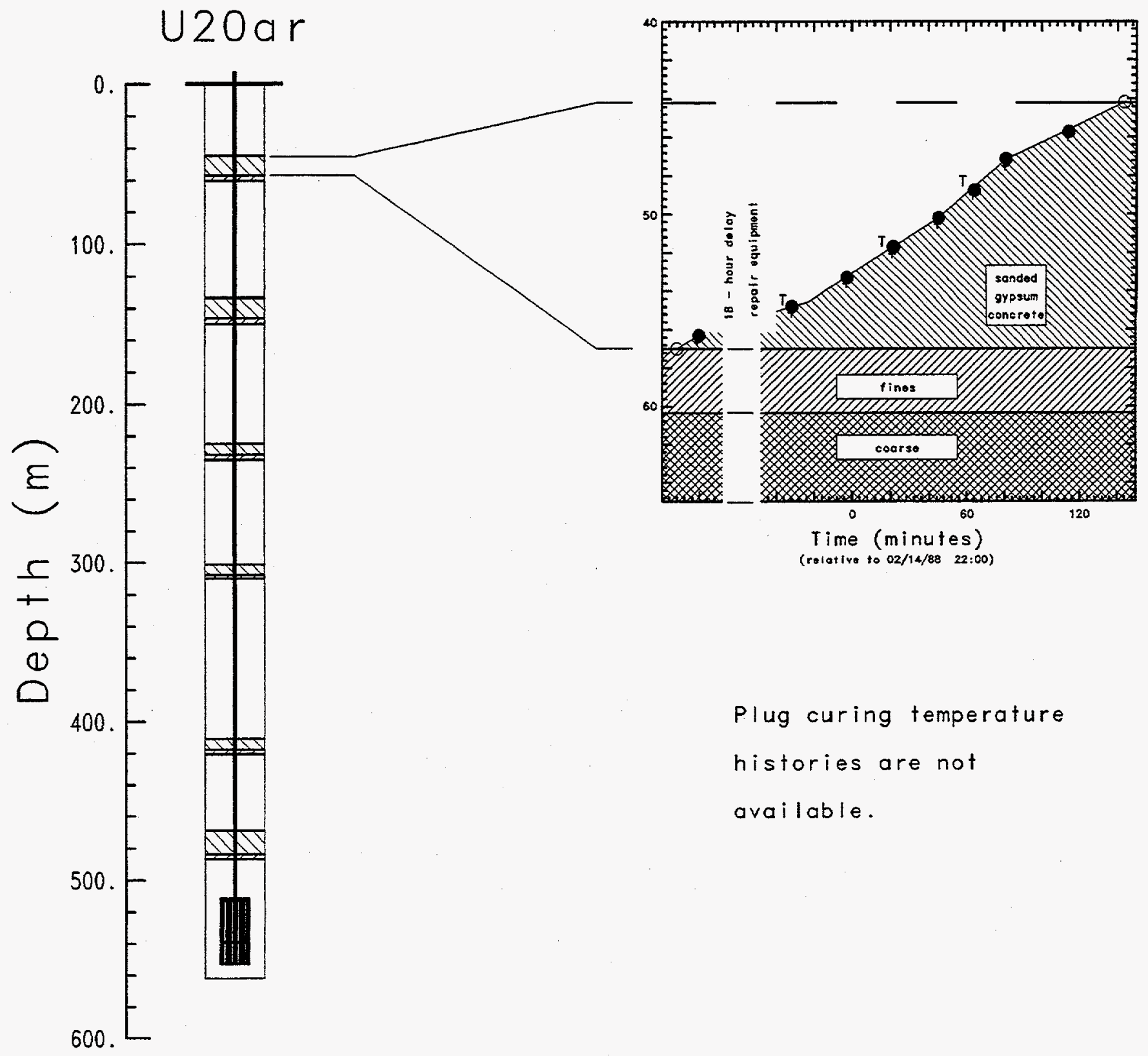

Figure 2.7 Emplacement diagnostics data at SGC plug \#6. The upper and lower boundaries of the plug were determined with a tag line. Solid symbols indicate the elevation of the probes; open symbols are at the tag depths. Probes annotated with ' $T$ ' included temperature sensors. 


\section{Stemming Performance}

Pressure and radiation were not monitored down the hole on this event. No radiation was detected above ground Containment of KERNVILLE was considered satisfactory.

Atmospheric pressure was monitored by a transducer mounted inside the recording trailer and ported through the wall to the outside. The recording time period (about 3 hours) was too short to sample the gross changes in the atmosphere, the porting precluded an accurate representation of the airblast waveform, and the signal included many noise spikes. For these reasons the signal is not shown in this report.

The EXCOR signal (station 51 , in the satellite hole) was terminated very shortly after detonation. This allowed only one datum from which to determine the position of cable breakage. With no other corroborating data, the EXCOR is assumed to have malfunctioned and is not presented. All other data derived from the satellite hole were yield-related measurements and may be obtained from reference 4 .

\section{Motion}

Figures 4.1 and 4.2 show the explosion- and collapse-induced motion of the ground surface $15.24 \mathrm{~m}$ from SGZ. Figures $4.3,4.4$, and 4.5 show the three components of the explosion-induced trailer motion. Motion of the trailer during collapse was too small to be meaningfully processed and is thus not shown. For completeness, the signals from the geophone station are shown in Figure 4.6. These have not been converted to engineering units since, for the most part, they exceeded the dynamic range of the recording system.

Motion arrival times and peaks are given in Table 4.1. Characteristics of the motion transducers are given in Tables 4.2 and 4.3. 


\section{Table 4.1 Summary of Motion}

\begin{tabular}{|c|c|c|c|c|c|c|}
\hline Gage & $\begin{array}{l}\text { Slant Range } \\
\text { (m) }\end{array}$ & $\begin{array}{l}\text { Arrival Time } \\
\text { (ms) }\end{array}$ & $\begin{array}{c}\text { Acceleration } \\
\text { Peak (g) }\end{array}$ & $\begin{array}{c}\text { Velocity Peak } \\
(\mathrm{m} / \mathrm{s})\end{array}$ & $\begin{array}{c}\text { Displacement } \\
\text { Peak (m) }\end{array}$ & $\begin{array}{l}\text { Displacement } \\
\text { Resid. (cm) }\end{array}$ \\
\hline $61 a v$ & 540 & 296 & $3.44,12.2^{(a)}$ & 4.7 & 2.13 & 0 \\
\hline 61uv & - & - & - & 4.3 & 1.88 & -.10 \\
\hline $71 a v$ & 605 & 380 & 2.8 & 3.5 & 0.80 & 0.30 \\
\hline $71 u v$ & - & - & - & 3.10 & 0.77 & 0.13 \\
\hline 71 ar & 605 & 390 & $1^{(b)}$ & 1.13 & 0.90 & 0.15 \\
\hline $71 u r$ & - & - & - & 1.18 & 0.92 & 0.13 \\
\hline 71at & 605 & 385 & $-.25^{(b)}$ & $-.15,0.85$ & $-0.05,0.37$ & 0.2 \\
\hline $\begin{array}{l}71 \text { ut } \\
\text { (a) Sla } \\
\text { (b) Tor }\end{array}$ & $\begin{array}{c}\text { - } \\
\text { - down peak. } \\
\text { noisy to accu }\end{array}$ & determine & - & $-.17,0.80$ & $-0.05,0.39$ & 0.07 \\
\hline
\end{tabular}


Table 4.2 Accelerometer Characteristics

\begin{tabular}{cccc} 
Gage & $\begin{array}{c}\text { Natural Frequency } \\
(\mathrm{Hz})\end{array}$ & Damping Ratio & $\begin{array}{c}\text { System Range } \\
(\mathrm{g} / \mathrm{s})\end{array}$ \\
\cline { 2 - 4 } 61av & 380 & .75 & 24 \\
71 av & 350 & .62 & 20 \\
71 ar & 420 & .85 & 15 \\
71 at & 300 & .55 & 7.5
\end{tabular}

(a) All gages were manufacturer by Validyne, Inc.

\section{Table 4.3 Velocimeter Characteristics}

\begin{tabular}{|c|c|c|c|c|c|}
\hline Gage & $\begin{array}{c}\text { Natural } \\
\text { Frequency } \\
(\mathrm{Hz})\end{array}$ & $\begin{array}{l}\text { Time to } 0.5 \\
\text { Amplitude } \\
\text { (s) }\end{array}$ & $\begin{array}{c}\text { Calibration } \\
\text { Temperature } \\
\left({ }^{\circ} \mathrm{C}\right)\end{array}$ & $\begin{array}{c}\text { Operate } \\
\text { Temperature } \\
\left({ }^{\circ} \mathrm{C}\right)\end{array}$ & $\begin{array}{c}\text { System } \\
\text { Range } \\
(\mathrm{m} / \mathrm{s})\end{array}$ \\
\hline 61UV & 3.375 & 8.34 & 24.80 & 2.44 & 16 \\
\hline 71UV & 3.515 & 9.28 & 25.25 & 14.9 & 7 \\
\hline 71ur & 3.334 & 9.40 & 24.95 & 14.99 & 5 \\
\hline 71ut & 3.315 & 9.29 & 25.01 & 14.99 & 5 \\
\hline
\end{tabular}



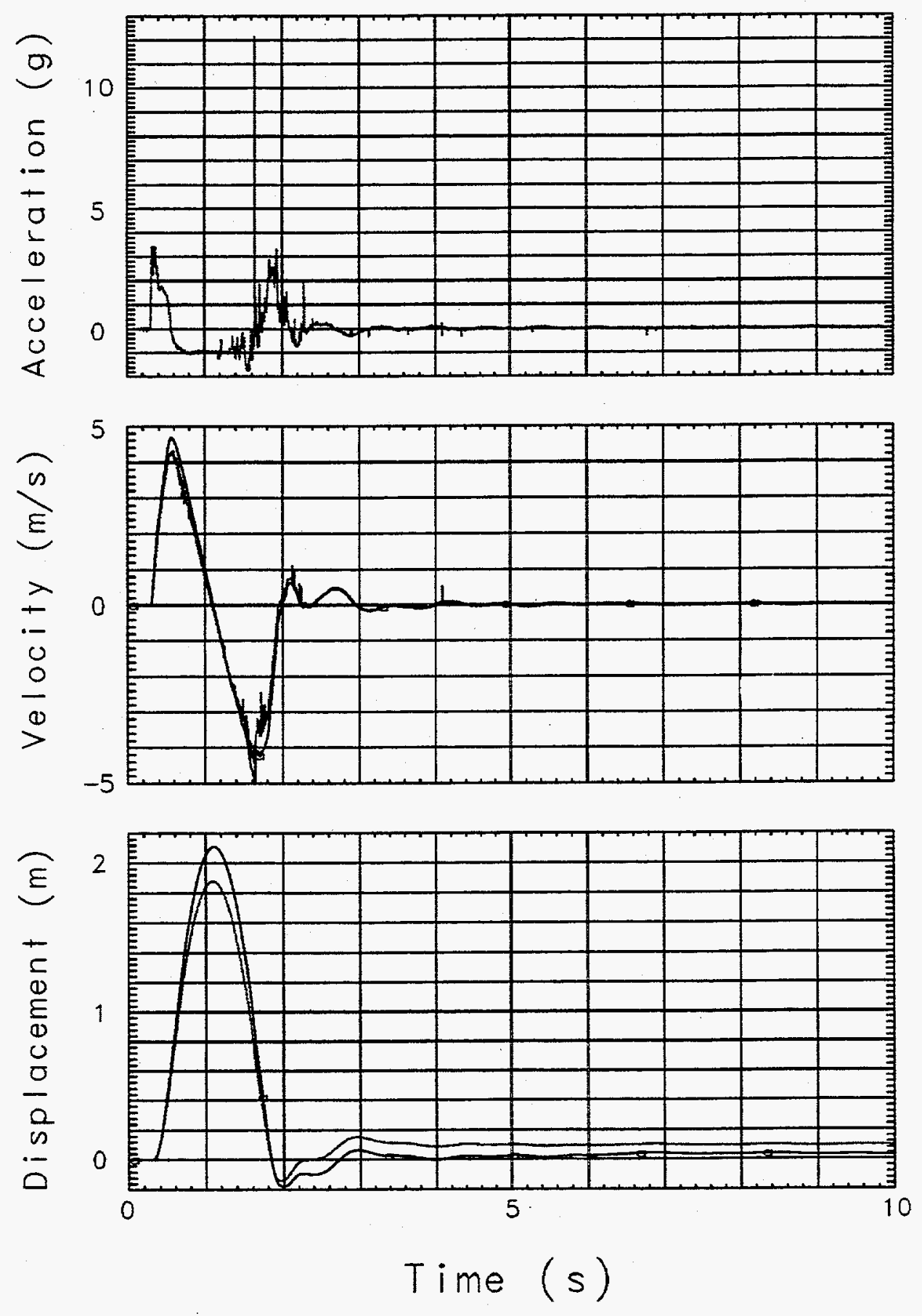

Figure 4.1 Explosion-induced vertical motion of ground surface $15.24 \mathrm{~m}$ from SGZ (Station 61). Traces annotated with "a" are derived from the accelerometer history. 

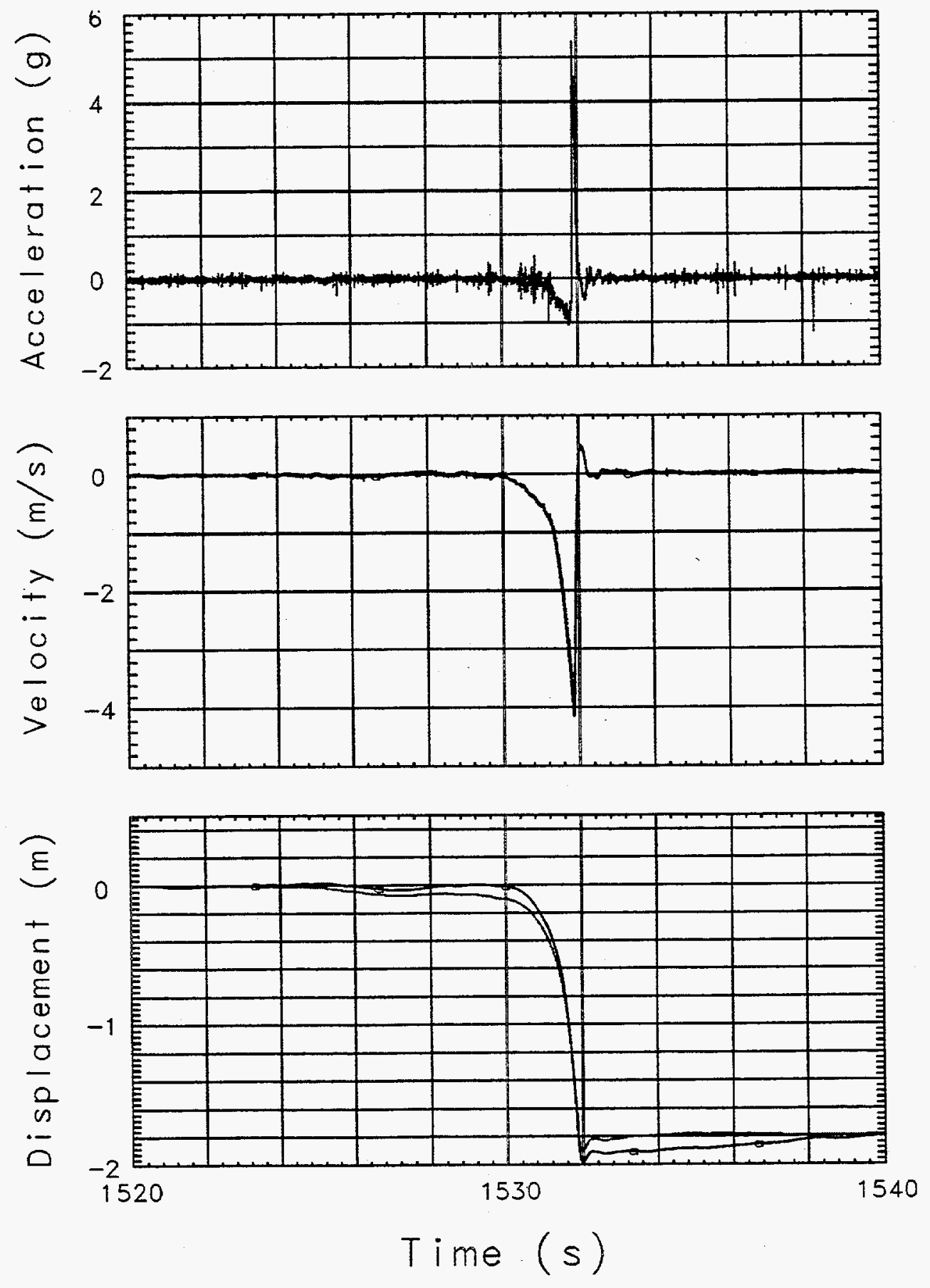

Figure 4.2 Collapse-induced vertical motion of ground surface $15.24 \mathrm{~m}$ from SGZ (Station 61). Traces annotated with "a" are derived from the accelerometer history. 

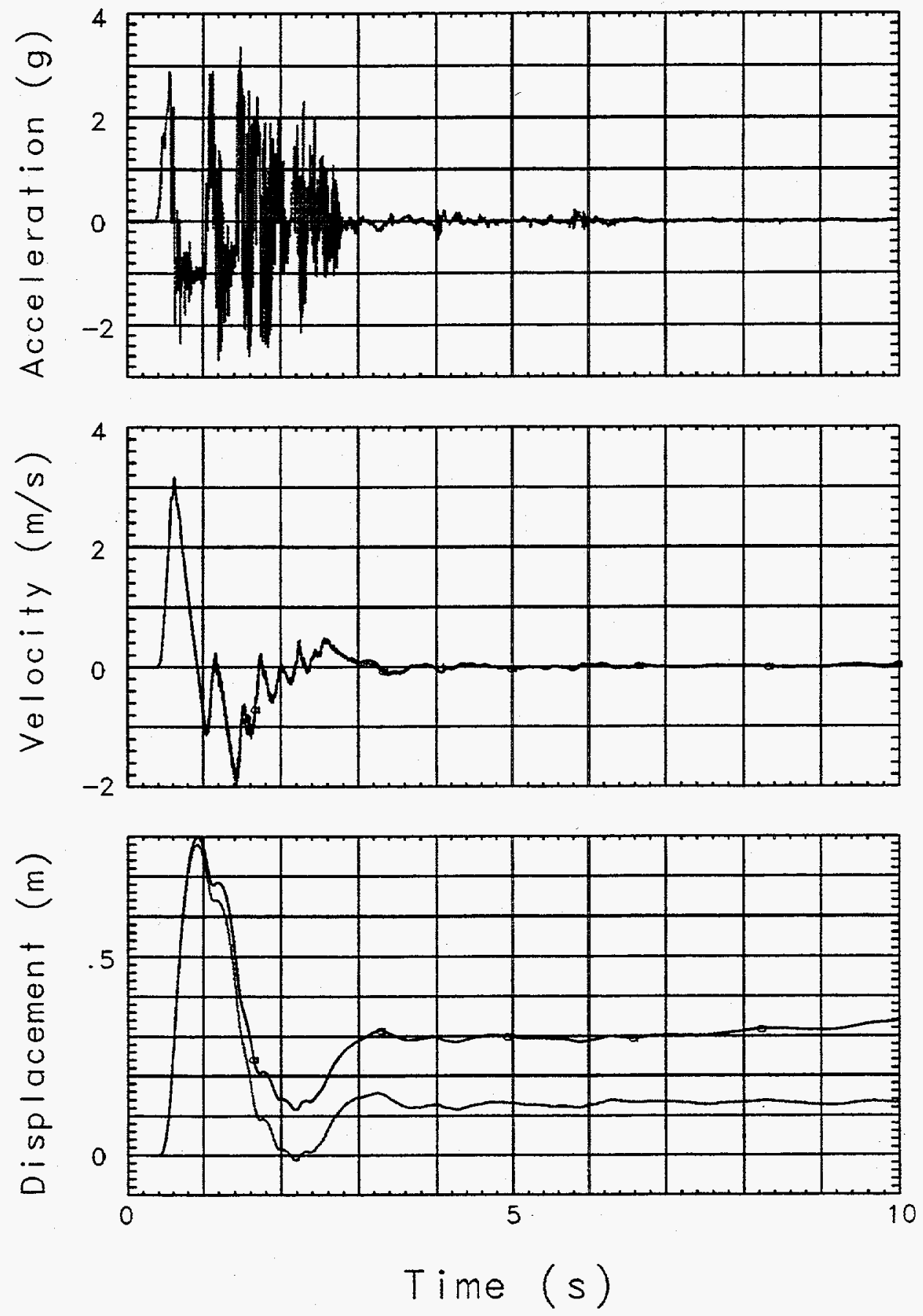

Figure 4.3 Explosion-induced vertical motion of recording trailer about $270 \mathrm{~m}$ from SGZ (Station 71). Traces annotated with "a" are derived from the accelerometer history. 

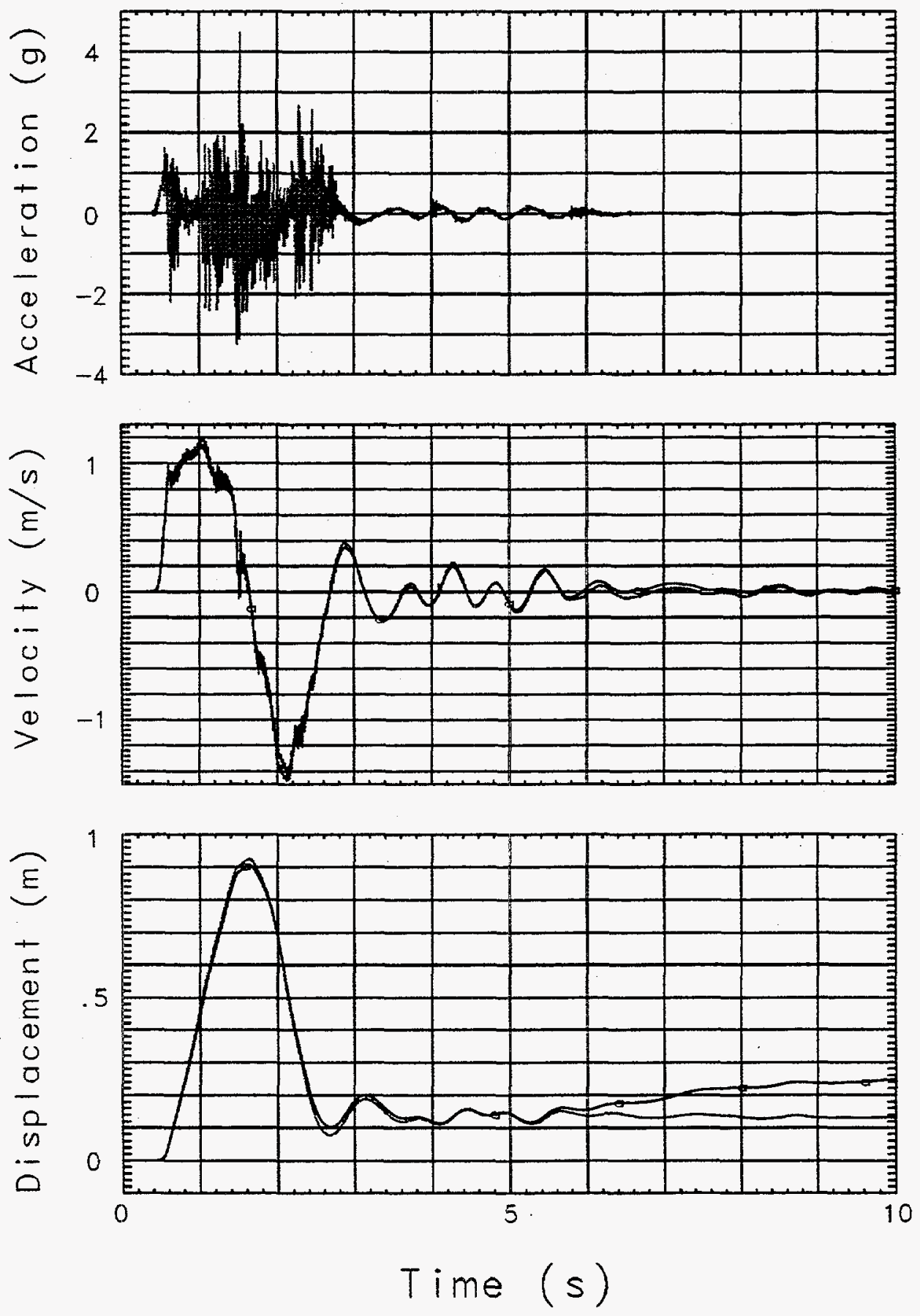

Figure 4.4 Explosion-induced horizontal-radial motion of recording trailer about $270 \mathrm{~m}$ from SGZ (Station 71). Traces annotated with "a" are derived from the accelerometer history. 

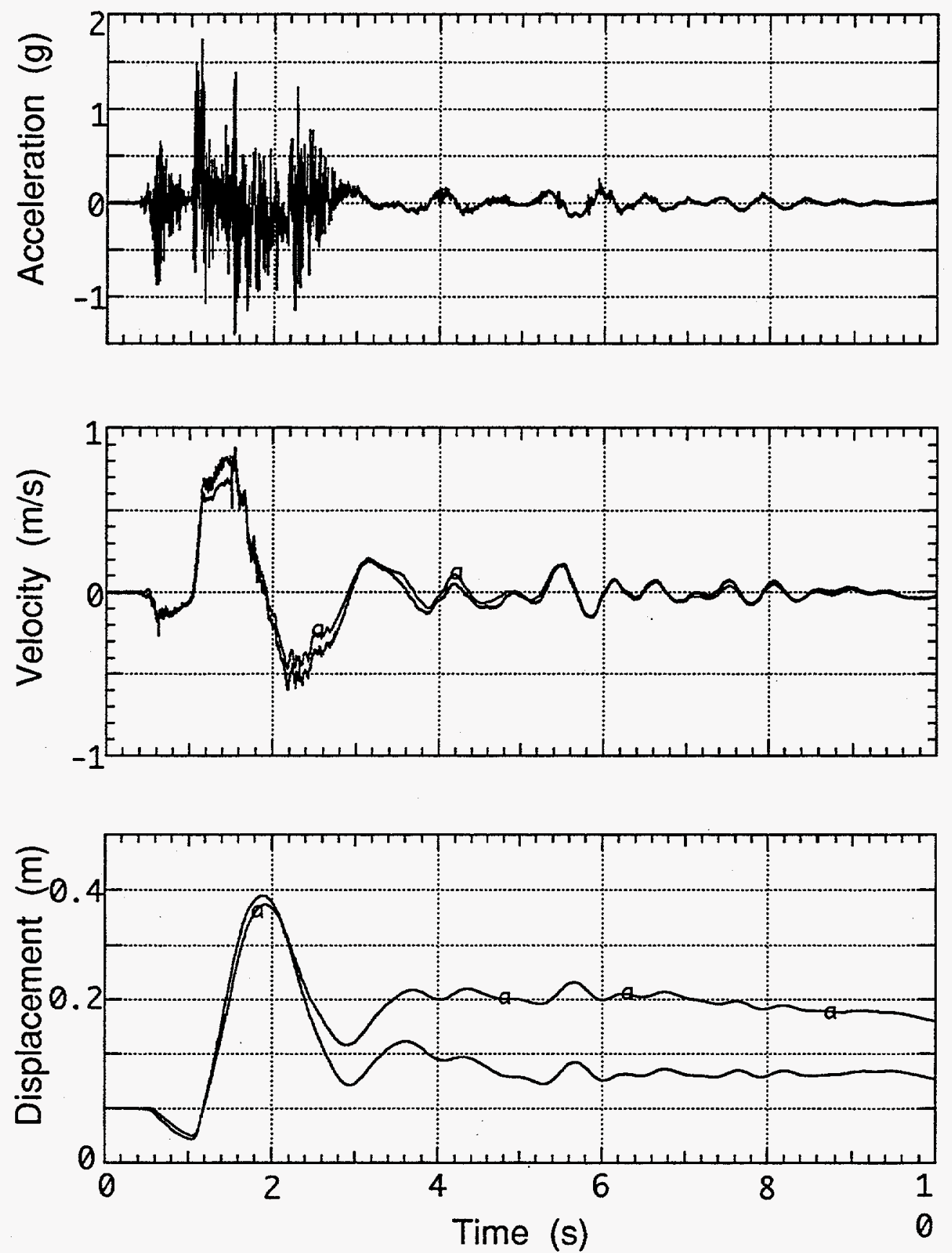

Figure 4.5 Explosion-induced horizontal-transverse motion of recording trailer about $270 \mathrm{~m}$ from SGZ (Station 71). Traces annotated with "a" are derived from the accelerometer history. 


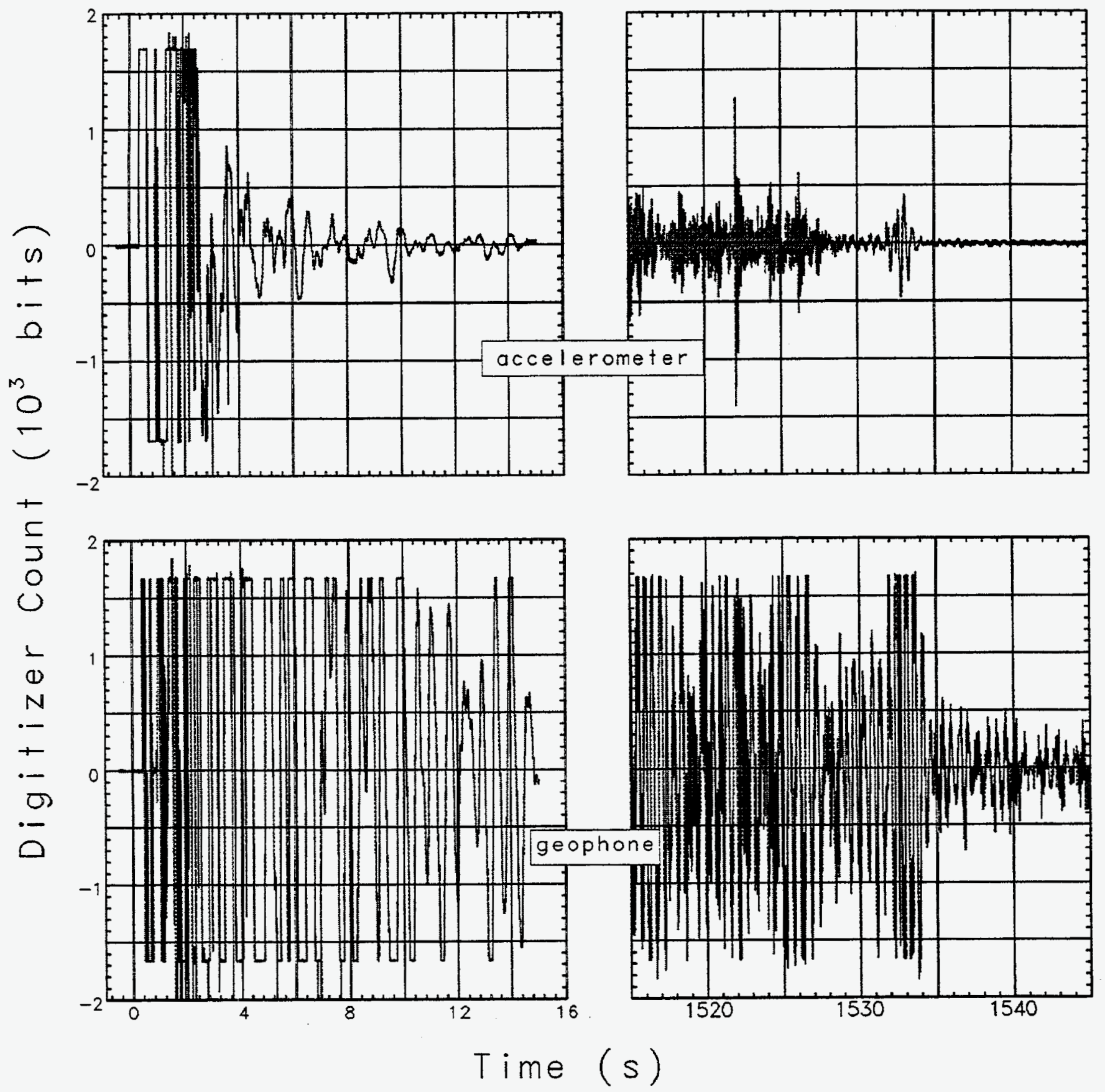

Figure 4.6 As-digitized explosion- and collapse-induced signals recorded at the geophone station in the ground surface near the recording trailer about $270 \mathrm{~m}$ from SGZ (Station 62). The only processing of these records was to set the baseline to zero digitizer counts. 


\section{References}

1. Steve Clark, Robin Newmark, and Dick McArthur, "U20ar Site Characteristics Report", Lawrence Livermore National Laboratory, CP 87-26, March 16, 1987.

2. R. Hutchinson (for S. L. Doney), "Emplacement and Containment Report for KERNVILLE U20ar," Holmes \& Narver, Inc., NTS:A2:88-14, February 14,

3. B. Bellow, "Special Measurements Physics/Instrumentation, KERNVILLE, U20ar", EG\&G, energy Measurements, Las Vegas Operations, SM:87E-144-37, Sept.1,1988.

4. LLNL contacts for additional information: $H$. Goldwire (CORRTEX and SLIFER data). 
Distribution:

LLNL

TID (11)

Test Program Library

Containment Vault

Burkhard, N.

Cooper, W.

Denny, $M$.

Dong, $R$.

Goldwire, $\mathrm{H}$

Heinle, R. (5)

Mara, $G$.

Moran, M.T.

Moss, W.

Olsen, C.

Patton, $\mathrm{H}$,

Pawloski, G.

Rambo, J.

Roland, $\mathrm{K}$.

Roth, B.

Valk, $T$.

Younker, L.

LANL

App, F.

Brunish, W.

Kunkle, $T$.

Trent, B.

\section{Sandia}

Chabai, A.

Smith, Carl W.
$L-053$

L-045

L-221

L-221

L-049

L-205

L-140

L-221

L-221

L-049

L-777

L-200

L-221

L-205

L-221

L-200

$L-221$

L-049

L-154

L-203

F-659

F-659

F-665

F-664

MS-1159

MS-1159
EG\&G/AVO

Brown, $T$.

A-5

Gilmore, L. A-1

Hatch, M. A-5

Still, G. A-5

Stubbs, T. A-5

\section{EG\&G/NVO}

Bellow, B.

N $13-20$

Davies, $\mathrm{L}$.

Moeller, A.

$N 13-20$

Robinson, R. N 13-20

Webb, W.

N 13-20

DNA

Ristvet, B.

S-Cubed

Peterson, $E$.

Eastman Cherrington Environment

1640 Old Pecos Trail, Suite H

Santa Fe, NM 87504

Keller, C. 